\title{
Effects of Extrusion Processing on the Proximate Compositions of Aerial Yam (Dioscorea bulbifera)-soybean (Glycine max) Flour Blends Using Response Surface Methodology
}

\author{
Enobong O. Umoh ${ }^{1} \&$ Madu O. Iwe ${ }^{2}$ \\ ${ }^{1}$ Department of Agricultural Engineering, AkwaIbom State University, IkotAkpaden, Nigeria \\ ${ }^{2}$ Department of Food Science and Technology, Michael Okpara University of Agriculture, Umudike, Abia State, \\ Nigeria \\ Correspondence: Enobong O. Umoh, Department of Agricultural Engineering, AkwaIbom State University, \\ IkotAkpaden, P.M.B., 1167, Uyo, AkwaIbom State, Nigeria. Tel: 234-803-540-8924. E-mail: \\ enoumoh40@gmail.com
}

Received: November 8, 2021

Accepted: January 21, $2022 \quad$ Online Published: January 23, 2022

doi:10.5539/jfr.v11n1p38

URL: https://doi.org/10.5539/jfr.v11n1p38

\begin{abstract}
The impact of extrusion process parameters on the proximate compositions of aerial yam (Dioscorea bulbifera)-soybean (Glycine max) flour blends was investigated with the help of a laboratory scale single-screw extruder, and the flour blending ratio of $25 \%$ aerial yam: $75 \%$ soybean. Response surface methodology based on Box-Behken design at three factors, five levels of barrel temperature $\left(95,100,105,110\right.$, and $\left.115^{\circ} \mathrm{C}\right)$, screw speed $(85,100,115,130$, and145rpm) and feed moisture $(31,33,35,37$, and $39 \%)$ were used in 20 runs. Adequate and significant $(p<0.05)$ regression models describing the effects of process parameters on the product quality attributes with high regression coefficient, $R^{2} \geq 0.9$ were obtained, showing that the models can be used to navigate the design space. Results obtained showed that the proximate compositions ranged between $4.03 \pm 0.002$ and $5.90 \pm 0.002 \%$ ash; $3.10 \pm 0.001$ and $7.02 \pm 0.003 \%$ moisture content; $2.70 \pm 0.001$ and $4.67 \pm 0.003 \%$ fibre; $24.57 \pm 0.078$ and $36.79 \pm 0.004 \%$ protein; $11.39 \pm 0.004$ and $35.35 \pm 0.011 \%$ lipid. The best extrusion condition combinations were $115^{\circ} \mathrm{C}$ barrel temperature, $115 \mathrm{rpm}$ screw speed and $35 \%$ feed moisture for ash content; $100^{\circ} \mathrm{C}$ barrel temperature, $130 \mathrm{rpm}$ screw speed and $33 \%$ feed moisture for moisture content; $115^{\circ} \mathrm{C}$ barrel temperature, $115 \mathrm{rpm}$ screw speed and $35 \%$ feed moisture for fibre content; $105^{\circ} \mathrm{C}$ barrel temperature, $145 \mathrm{rpm}$ screw speed and $35 \%$ feed moisture for protein content; $105^{\circ} \mathrm{C}$ barrel temperature, $85 \mathrm{rpm}$ screw speed and $35 \%$ feed moisture for lipids. Analysis of variance showed that only barrel temperature affected the ash composition significantly $(p<0.05)$. Barrel temperature, screw speed and feed moisture showed insignificant $(p>0.05)$ effect on moisture content, while fibre content was significantly $(p<0.05)$ affected by barrel temperature and screw speed. Protein and crude fat (lipid) contents were significantly $(p<0.05)$ affected by barrel temperature, screw speed and feed moisture.
\end{abstract}

Keywords: extrusion, aerial yam, soybean, proximate compositions, response surface

\section{Introduction}

As indicated by Iwe (2003), food extrusion has been in practice for over sixty years. Extrusion cooking is a significant and famous food handling strategy named a high temperature/short time frame (HTST) interaction to create fiber-rich items (Gaossong and Vasanthan, 2000). It is an interaction where dampened, sweeping, bland and additionally proteinacious food materials are plasticized and cooked in a cylinder by a mix of dampness, tension, temperature and mechanical shear, bringing about atomic change and substance responses (Castells et al., 2005).

The utilization of expulsion cooking in non-industrial nations for nearby creation of precooked oat based mixes planned as weaning nourishment for taking care of projects was accounted for since the 1960s. It is all around recorded that when grain and vegetable protein are mixed, the protein nature of the blend surpasses that of the singular parts. As indicated by Iwe (1997), maintenance of supplements is upgraded by the utilization of such cycles as expulsion cooking.

Aerial yam (Dioscorea bulbifera) is an assortment of sweet potato filled in certain regions of the planet. This 
bulbils-bearing sweet potato has a place with the request Dioscoreal, Family Dioscoreaceae, and Genus, Dioscorea, and is a disliked species among the eatable sweet potato species. It is developed in the Southeast Asia, West Africa, and South and Central America. The wild structure additionally happens in both Asia and Africa (Nwosu, 2013). Airborne sweet potato (Dioscorea bulbifera) is recorded to be a disagreeable sweet potato among the palatable sweet potato species which not at all like the conventional sweet potato produces aeronautical bulbils that seem as though potatoes, hence the name, flying/air potatoes (Ojinnaka et al., 2017).

This type of sweet potato is consumed by few networks and is by and large underutilized both at means and business levels for various reasons (Igyor et al., 2004). These incorporate, having a generally harsh delayed flavor impression contrasted with other sweet potato species,

obscured to a great many people, and much work has not been done on it to recommend utilizations to which it very well may be put to. Notwithstanding, there are loads of possibilities for arial yam as far as dietary and practical properties could be exploited to deliver assorted modern items, just as its financial significance (Sanful and Engmann, 2016).

Dioscorea bulbifera has been generally utilized in the Chinese clinical framework as a significant spice during the time spent modifying and keeping up with kidney work (Ahmed et al., 2009). This spice was likewise answered to have a gainful impact in treating illnesses of the lungs and spleen, and many kinds of loose bowels, further developing assimilation and digestion (Coursey, 1967). In Asia, this spice has been strongly suggested for treating diabetes. It has been generally used to bring down glycemic index, giving a more supported type of energy and better insurance against weight and diabetes; be that as it may, this property has not yet been logically demonstrated (Brand-Miller et al., 2003).

Aerial Yam (Dioscorea bulbifera), being a lesser realized food crop, has not been handled to any huge degree industrially. It is just a little piece of the yield that is handled into moment sweet potato flour which is especially famous in Yoruba talking areas of West Africa, yet less so in different pieces of the mainland (Orkwor et al., 1998)

Handling Aerial sweet potato to flour can assist with diminishing the over reliance on wheat flour for our prepared items and post - collect misfortunes (Prnce-will and Ezembaukwu, 2015).

Soybean (Glycine max), a significant oil seed having a place with the family, Leguminosae, is normally developed as a food crop. Three types of soybean exist. They include: Glycine ussuriensis-wild, Glycine max-developed and Glycine gracillis-transitional. Glycine max is normally developed all through the world as a material of trade. Soybean creation and use as food emerged in antiquated China not later than the eleventh Century B.C. It then, at that point, became filled in different regions of the planet simply in the twentieth Century. The major creating nations are the United States, Brazil, China, and Argentina (Iwe, 2003).

Soybean is predominantly developed for its seeds, utilized as human food and animals feed, and for the extraction of oil. Soy food varieties are turning into the absolute quickest developing classes in the food business, with items going from customary soy food varieties to protein fixings, and from dairy and meat options in contrast to different sorts of Western and conventional food sources enhanced with soybean flour as well as its parts (Iwe, 2003).

In any case, mixing of aerial yam and soybean, and additionally extrusion cooking of the mix, has not been sufficiently read up for its likely application in food items plan.

The review will be helpful and intriguing on the grounds that very little exploration work has been done on the food esteem/potential food worth of aerial yam in the space of extrusion handling.

Aerial yam is yet to acquire acknowledgment and prevalence universally, as a food crop. Handling it into stable flour/mix, and resulting extrusion handling to deliver pasta, will expand the perceivability of the yield in food exchange, accordingly bringing to spotlight its potential food uses/qualities to the food business.

Also, the augmentation of known strategies for food handling, similar to extrusion cooking, and use of Aerial sweet potato (Dioscorea bulbifera) past the Pharmacological perspective could mean presenting new methods and food items, accordingly offering assortment to customers.

The aim/objective of this study is to determine the effects of extrusion process variables or parameters on the proximate compositions of aerial yam-soybean flour blend using a response surface methodology.

\section{Materials and Methods}

Soybean seeds and Aerial yam bulbs used in this study were purchased from Uyo Urban market in Uyo Local Government Area, Akwalbom State, Nigeria. 


\subsection{Preparation of Aerial Yam Flour}

Aerial yam flour was prepared according to the method described by Olurin et al. (2006). The Aerial yam bulbs were cleaned and sorted to remove unwanted materials, before peeling with knife, washed with cleaned water and sliced to $10 \mathrm{~mm}$ thickness using knife. The slices (chips) were then dried, using an oven at a temperature of $60^{\circ} \mathrm{C}$ for $12 \mathrm{~h}$. The dried slices (chips) were then milled using a hammer mill and sieved with laboratory sieve of $600 \mu \mathrm{m}$ aperture size. The flour obtained was packaged in a polyethene bag for subsequent use.

\subsection{Preparation of Soybean Flour}

Soybean flour was prepared according to the method described by Iwe (2003). Seeds were screened to remove foreign materials, splits, and damaged beans. This was followed by washing and roll boiling at $100^{\circ} \mathrm{C}$ for 30 minutes. It was then oven -dried at a temperature of $70^{\circ} \mathrm{C}$ for $12 \mathrm{~h}$, and milled in a disc attrition mill. The milled full-fat soybean was sieved using a 100-mesh standard sieve. The flour obtained was then stored in air- tight polyethene bag at room temperature $\left(\right.$ about $22^{\circ} \mathrm{C}$ ) for further use.

\subsection{Preparation of Sample Blends}

The Aerial yam-Soybean flour blend was prepared in the ratio of 25:75, expressed in percentage as $25 \%$ aerial yam flour and $75 \%$ soybean flour.

\subsection{Extrusion Processing}

This was done with the help of a single-screw laboratory scale extruder in the Department of Food Science and Technology Laboratory, Federal University of Agriculture, Abeokuta, Ogun State, Nigeria. Two hundred grams $(200 \mathrm{~g})$ of the flour blend (25\% flying yam flour, $75 \%$ soybean flour) was precisely estimated and preconditioned by the ideal moisture levels, permitted to remain for around two minutes (2min) to guarantee uniform hydration of the natural substance. This was to guarantee that any dry center was disposed of (Strahm, 2000). The extruder was turned on, and the barrel temperatures and the screw speeds of the extruder were set accordingly. The natural substance was taken care of, through the container, into the extruder. The extrudates were gathered as they exit through the die, dried, and packaged in impenetrable zip lock polyethylene sacks for additional research facility investigation.

\section{Determination of Proximate Compositions}

The following Proximate analyses of the extruded aerial yam-soybean flour blend were carried out according to the Official Methods of Analysis (AOAC, 1990).

\subsection{Moisture Content}

The weight of a washed and oven dried beaker was taken after cooling in a desiccators (a). Two grams (2g) of the flour blend sample was introduced into the weighed beaker and the weight of the beaker plus sample was taken (b). The beaker with its content was dried in an oven at $105^{\circ} \mathrm{C}$ for $4 \mathrm{~h}$ after which was quickly transferred into a desiccator to cool, then reweighed. This procedure was repeated till a constant weight was obtained (c).

Calculation:

$$
\text { MoistureContent }(\%)=\frac{\text { lossinweightduetodrying }}{\text { weightofsampletaken }}=\frac{b-c}{b-a} \times 100
$$

\subsection{Ash Content}

A crucible with lid was ignited in a muffle furnace, Model SXL-1200, at $105^{\circ} \mathrm{C}$ for $1 \mathrm{hr}$. It was then transferred to a dessicator to cool and weighed (a).

Two grams (2g) of the flour blend sample was put into the pre-weighed crucible and its content (flour sample) was taken (b). The crucible and its content was charred using Bunsen flame in a fume cupboard, until smoking ceased. It was then moved to muffle furnace, at $550^{\circ} \mathrm{C}$ for $2 \mathrm{~h}$. The crucible taken out, cooled, covered and placed in a dessicator and weighed (c).

Calculation:

$$
\operatorname{Ash}(\%)=\frac{\text { weightof Ash }}{\text { weightofsample }} X 100=\frac{b-C}{b-a} \times 100
$$

\subsection{Crude Fibre}

Two grams $(2 \mathrm{~g})$ of the sample was defatted with petroleum ether for $2 \mathrm{~h}$. It was boiled for 30 minutes with $200 \mathrm{ml}$ of $\mathrm{H}_{2} \mathrm{SO}_{4}$ solution, filtered through linen on a fluted funnel and washed with boiling water until the washings 
were no longer acidic.

The residue was moved to a beaker and boiled for an additional 30 minutes with $200 \mathrm{ml}$ of $\mathrm{NaOH}$ arrangement, separated and the last residue washed with bubbling water a few times until was base $(\mathrm{NaOH})$ free.

The residue was at long last washed two times with methanol, quantitatively moved into a pre-gauged cauldron, and broiler dried at $105^{\circ} \mathrm{C}$ (Io). It was burned in a heater at $550^{\circ} \mathrm{C}$, cooled in a dessicator and gauged (Ia). The misfortune in weight after cremation was likewise taken.

Calculation:

$$
\text { Crudefibre }(\%)=\frac{I_{a-I_{o}}}{\text { weightoforiginalsampletaken }} \times 100
$$

\subsection{Crude Protein}

Crude protein was determined by Kjeldahl method. One gram $(1 \mathrm{~g})$ of the flour sample was accurately weighed into a standard $250 \mathrm{ml} \mathrm{Kjeldahl} \mathrm{flask} \mathrm{containing} 1.5 \mathrm{~g} \mathrm{CuSO}_{4}$ and $1.5 \mathrm{~g} \mathrm{Na}_{2} \mathrm{SO}_{4}$ as catalyst and $5 \mathrm{ml}$ conc. $\mathrm{H}_{2} \mathrm{SO}_{4}$.

The kjeldahl flask (digestion) was placed on a heating mantle and was heated gently to prevent frothing, for some hours until a clear bluish solution was obtained. The digested solution was allowed to cool and was quantitatively transferred to $100 \mathrm{ml}$ standard flask, made up to the mark with distilled water. Twenty millilitres $(20 \mathrm{ml})$ portion of the digest was pipetted into a semi micro kjeldahl distillation apparatus and treated with equal volume of $40 \% \mathrm{NaOH}$ solution. The ammonia evolved was steam distilled into $100 \mathrm{ml}$ conical flask containing $10 \mathrm{ml}$ solution of saturated boric acid to which 2 drops of Tashirus indicator (double indicator) had been added.

The tip of the condenser was immersed into the boric acid - double indicator solution and then the distillation continued until about $2 / 3$ of the original volume was obtained. The tip of the condenser was then rinsed with a few millilitres of distilled water in the distillate which was then titrated with $0.1 \mathrm{M} \mathrm{HCl}$ solution until a purple-pink end-point was observed.

A blank determination was also carried out in the similar manner as described above except for the omission of the sample. The crude protein was obtained by multiplying the $\%$ Nitrogen content by a factor (6.25). Crude protein $=\%$ Nitrogen $\mathrm{X}$ factor.

Calculation:

$$
\frac{(\text { Sample titre - blank titre) } 0.1 \times 0.014}{\text { Weight of sample }} \times \frac{100}{20} \times \frac{100}{1} \times 6.25
$$

\subsection{Crude Fat (Lipid)}

Two grams ( $2 \mathrm{~g}$ ) of the flour blend sample was weighed into extraction thimble, which had already been washed, oven dried and lightly plugged with cotton wool.

One hundred and fifty millilitres $(150 \mathrm{ml})$ of petroleum ether with boiling point between 35 to $60^{\circ} \mathrm{C}$, was poured into a $500 \mathrm{ml}$ capacity round bottom flask. The soxhlet extractor was fitted into the round bottom flask which was seated on a heating mantle. The soxhlet apparatus was assembled and allowed to reflux for about $4 \mathrm{~h}$.

The extract was poured into a dried pre-weighed beaker $\left(\mathrm{W}_{1}\right)$ and the thimble rinsed with a little quantity of the ether back to the beaker.The beaker was heated on a steam bath to drive off the excess solvent, cooled in a desiccators and weighed $\left(\mathrm{W}_{2}\right)$.

Calculation:

$$
\begin{gathered}
\frac{\text { Weight gain in flask }}{\text { Weight of sample }} \times \frac{100}{1} \\
\text { Crude fat }(\%)=\frac{\mathrm{W} 2-\mathrm{W} 1}{\text { Weight of sample }}+\frac{100}{1}
\end{gathered}
$$

\section{Experimental Design/ Statistical Analysis}

Design Expert (version 11.0.1), a Statistical Computer Application Software Package was used in the experimental design/layout. Central Composite Randomized Design (CCRD) was used with a three factor experimental set up at five levels each, with barrel temperature $\left(X_{1}\right)$, screw speed $\left(X_{2}\right)$ and feed moisture levels $\left(X_{3}\right)$ as the independent factors (Table 1). Response Surface Methodology (RSM) was used to analyze the effects 
of the independent factors or variables on the dependent variables (the responses). Coded values for the independent variables used were $-2,-1,0,1,2$, where -2 represents the lowest, 0 represents the medium (mid-point), and 2 represents highest levels respectively ( Tables 1).

Table 1. Coded and actual values of different experimental variables

\begin{tabular}{|c|c|c|c|c|c|c|c|c|}
\hline \multirow[t]{2}{*}{ Factors } & \multirow[t]{2}{*}{ Units } & \multirow[t]{2}{*}{ Codes } & \multicolumn{5}{|c|}{ Levels } & \multirow[t]{2}{*}{ Interval of Variation } \\
\hline & & & -2 & -1 & 0 & 1 & 2 & \\
\hline Barrel temp. & ${ }^{\circ} \mathrm{C}$ & $X_{1}$ & 95 & 100 & 105 & 110 & 115 & 5.0 \\
\hline Screw speed & $\mathrm{rpm}$ & $X_{2}$ & 85 & 100 & 115 & 130 & 145 & 15.0 \\
\hline Feed moisture & $\%$ & $X_{3}$ & 31 & 33 & 35 & 37 & 39 & 2.0 \\
\hline
\end{tabular}

\section{Results and Discussion}

The results of the effects of extrusion processing on the proximate composition of aerial yam-soybean flour blends are presented in Table 2

Table 2. Effect of Extrusion processing on the proximate composition of aerial yam-soybean flour Blends

\begin{tabular}{lllllllll}
\hline S/N & $\begin{array}{l}B T \\
\left({ }^{0} \mathrm{C}\right)\end{array}$ & $\begin{array}{l}S S \\
(\mathrm{rpm})\end{array}$ & $\begin{array}{l}F M \\
(\%)\end{array}$ & $\begin{array}{l}\text { Ash } \\
(\%)\end{array}$ & $\begin{array}{l}\text { Moisture content } \\
(\%)\end{array}$ & $\begin{array}{l}\text { Fibre } \\
(\%)\end{array}$ & $\begin{array}{l}\text { Protein } \\
(\%)\end{array}$ & $\begin{array}{l}\text { Crude } \\
\text { fat }(\%)\end{array}$ \\
\hline $\mathbf{1}$ & 105 & 115 & 31 & $5.07 \pm 0.003$ & $3.19 \pm 0.004$ & $3.57 \pm 0.002$ & $35.89 \pm 0.071$ & $23.86 \pm 0.005$ \\
$\mathbf{2}$ & 105 & 115 & 35 & $4.61 \pm 0.003$ & $3.86 \pm 0.004$ & $3.26 \pm 0.001$ & $25.88 \pm 0.199$ & $11.49 \pm 0.004$ \\
$\mathbf{3}$ & 105 & 115 & 35 & $4.56 \pm 0.003$ & $3.85 \pm 0.003$ & $3.19 \pm 0.001$ & $25.86 \pm 0.199$ & $11.41 \pm 0.004$ \\
$\mathbf{4}$ & 105 & 85 & 35 & $4.80 \pm 0.002$ & $4.20 \pm 0.003$ & $3.41 \pm 0.001$ & $31.89 \pm 0.177$ & $35.35 \pm 0.011$ \\
$\mathbf{5}$ & 100 & 130 & 33 & $5.48 \pm 0.002$ & $3.10 \pm 0.001$ & $3.79 \pm 0.002$ & $32.88 \pm 0.049$ & $24.96 \pm 0.014$ \\
$\mathbf{6}$ & 110 & 100 & 37 & $5.39 \pm 0.001$ & $3.78 \pm 0.001$ & $3.97 \pm 0.002$ & $32.08 \pm 0.127$ & $25.83 \pm 0.016$ \\
$\mathbf{7}$ & 100 & 100 & 37 & $4.20 \pm 0.003$ & $7.02 \pm 0.003$ & $2.70 \pm 0.001$ & $24.57 \pm 0.078$ & $16.79 \pm 0.062$ \\
$\mathbf{8}$ & 110 & 130 & 33 & $5.21 \pm 0.004$ & $4.86 \pm 0.003$ & $3.90 \pm 0.002$ & $35.14 \pm 0.021$ & $19.11 \pm 0.006$ \\
$\mathbf{9}$ & 105 & 115 & 35 & $4.67 \pm 0.003$ & $3.87 \pm 0.004$ & $3.21 \pm 0.001$ & $25.84 \pm 0.199$ & $11.43 \pm 0.004$ \\
$\mathbf{1 0}$ & 115 & 115 & 35 & $5.90 \pm 0.002$ & $3.21 \pm 0.002$ & $4.67 \pm 0.003$ & $35.97 \pm 0.099$ & $25.85 \pm 0.007$ \\
$\mathbf{1 1}$ & 95 & 115 & 35 & $5.19 \pm 0.001$ & $3.47 \pm 0.002$ & $3.58 \pm 0.002$ & $32.05 \pm 0.120$ & $30.54 \pm 0.011$ \\
$\mathbf{1 2}$ & 105 & 115 & 39 & $4.03 \pm 0.002$ & $4.77 \pm 0.003$ & $2.96 \pm 0.003$ & $30.17 \pm 0.099$ & $19.46 \pm 0.024$ \\
$\mathbf{1 3}$ & 105 & 115 & 35 & $4.69 \pm 0.003$ & $3.82 \pm 0.003$ & $3.20 \pm 0.001$ & 25.880 .199 & $11.39 \pm 0.004$ \\
$\mathbf{1 4}$ & 100 & 100 & 33 & $4.37 \pm 0.004$ & $3.47 \pm 0.003$ & $2.98 \pm 0.001$ & $33.25 \pm 0.148$ & $24.90 \pm 0.007$ \\
$\mathbf{1 5}$ & 110 & 130 & 37 & $5.01 \pm 0.002$ & $3.08 \pm 0.002$ & $3.70 \pm 0.002$ & $32.98 \pm 0.249$ & $20.34 \pm 0.012$ \\
$\mathbf{1 6}$ & 110 & 100 & 33 & $4.96 \pm 0.001$ & $3.17 \pm 0.002$ & $3.89 \pm 0.002$ & $34.59 \pm 0.092$ & $25.71 \pm 0.008$ \\
$\mathbf{1 7}$ & 105 & 145 & 35 & $5.32 \pm 0.002$ & $3.55 \pm 0.001$ & $4.05 \pm 0.003$ & $36.79 \pm 0.004$ & $28.90 \pm 0.121$ \\
$\mathbf{1 8}$ & 100 & 130 & 37 & $4.39 \pm 0.002$ & $3.69 \pm 0.004$ & $3.85 \pm 0.001$ & $30.26 \pm 0.021$ & $23.62 \pm 0.004$ \\
$\mathbf{1 9}$ & 105 & 115 & 35 & $4.65 \pm 0.003$ & $3.89 \pm 0.004$ & $3.24 \pm 0.001$ & $25.87 \pm 0.199$ & $11.46 \pm 0.004$ \\
$\mathbf{2 0}$ & 105 & 115 & 35 & $4.57 \pm 0.003$ & $3.85 \pm 0.004$ & $3.22 \pm 0.001$ & $25.83 \pm 0.199$ & $11.51 \pm 0.004$ \\
\hline
\end{tabular}

Note: Values are mean \pm standard deviation of triplicate determination.

$B T=$ Barrel Temperature, $S S=$ Screw Speed, $F M=$ Feed Moisture .

\subsection{Ash}

The results of the ash contents of the extruded aerial yam flour blends ranged from $4.03 \pm 0.002$ to $5.90 \pm 0.002 \%$ (Table 2). This range of values is higher than $1.45 \pm 0.02$ to $2.56 \pm 0.17$ for sorghum-based extruded product supplemented with defatted soy meal flour (Tadesseet al., 2019); $1.88 \pm 0.02$ to $2.91 \pm 0.01 \%$ for root and tuber composite flour noodles (Akonoret al.,2017) and $1.67 \pm 0.40$ to $3.00 \pm 0.58 \%$ for high quality cassava-Tiger nut extruded snacks (Kareem et al., 2015). This is an indication that extruded aerial yam-soybean flour blend is a potentially rich source of minerals.

\subsection{Moisture Content}

The results of the moisture contents of the extruded aerial yam-soybean flour are presented in Table 2. The moisture contents of the extrudates ranged from $3.10 \pm 0.001$ to $7.02 \pm 0.003 \%$. The observed low range of values for moisture content indicates that the extrudates can store for a long time without spoilage due to microbial activities. This range of values is low compared to $8.15 \pm 0.03$ to $8.66 \pm 0.09 \%$ for sorghum-based extruded product supplemented with defatted soy meal flour (Tadesse et al., 2019); and $5.25 \pm 0.35$ to $8.05 \pm 0.35 \%$ for 
high quality cassava-Tigernut extruded snacks (Kareem et al., 2015). In dry food systems, moisture content of between 6 and 10\% has been established to prolong the shelf life of foods, beyond which the storability of the system could be impeded by chemical and microbiological agents (Brncic et al., 2006).

\subsection{Fibre}

The results of the fibre contents of the extruded aerial yam-soybean flour blends are presented in Table 2 . The fibre content varied between $2.70 \pm 0.001$ and $4.67 \pm 0.003 \%$ (Table 2). This range of values is high compared to $0.83 \pm 0.02$ and $1.58 \pm 0.00 \%$ for sorghum-based extruded product supplemented with defatted soy meal flour (Tadesse et al., 2019); and 3.81 \pm 0.03 to $4.26 \pm 0.02$ for high quality cassava-Tiger nut extruded snacks (Kareem et al., 2015). The high range of values for fibre content is an indication that extrudates produced from aerial yam-soybean flour blends is a potential rich source of dietary fibre, which is necessary in the movement of food bowel and helps in the prevention of obesity, diabetes, cancer of the colon and other diseases of the gastro-intestinal tract of man (Dresden, 2021).

\subsection{Protein}

The results of the protein contents of the extruded aerial yam-soybean flour blends are presented in Table 2 . The results ranged from $24.57 \pm 0.078$ to $36.79 \pm 0.004 \%$. The observed range of values is higher, compared to $12.20 \pm$ 0.69 to $20.85 \pm 0.20 \%$ for sorghum-based extruded product supplemented with defatted soy meal flour (Tadesse et al., 2019); $10.90 \pm 0.06$ to $14.26 \pm 0.02 \%$ for root and tuber composite flour noodles (Akonor et al., 2017) and $3.09 \pm 1.36$ to $5.64 \pm 0.71 \%$ for high quality cassava-Tiger nut extruded snacks (Kareem et al., 2015). The high range of values for protein in the extrudates is attributed to the higher proportion of soybean flour (75\%), compared to the proportion of aerial yam flour $(25 \%)$ in the flour blend; Soybean has been reported to contain appreciable high percentage of protein. It can therefore be inferred that extrudates produced from aerial yam-soybean flour blends, at the ratio of 1:3 (25\%:75\%), is a potential rich source of protein required by humans for proper growth and development.

\subsection{Crude Fat (Lipid)}

The results of the percentage composition of lipids in the extruded aerial yam-soybean flour blend are presented in Table 2. The results of the lipids contents ranged between $11.39 \pm 0.004$ and $35.35 \pm 0.011 \%$. This observed range of values is higher compared to $3.06 \pm 0.06$ to $3.96 \pm 0.12 \%$ for sorghum-based extruded product supplemented with defatted soy meal flour (Tadesse et al., 2019); and $0.42 \pm 0.13$ to $22.28 \pm 0.25 \%$ for high quality cassava-Tiger nut extruded snacks (Kareem et al., 2015). The high crude fat content in the extrudates may be attributed to the full-fat soybean flour used as a component of the blends. The high fat content of the full-fat soybean flour may be attributed to the high crude fat contents of the extruded aerial yam-soybean flour blends.

\subsection{Impacts of Extrusion Process Parameters on Ash}

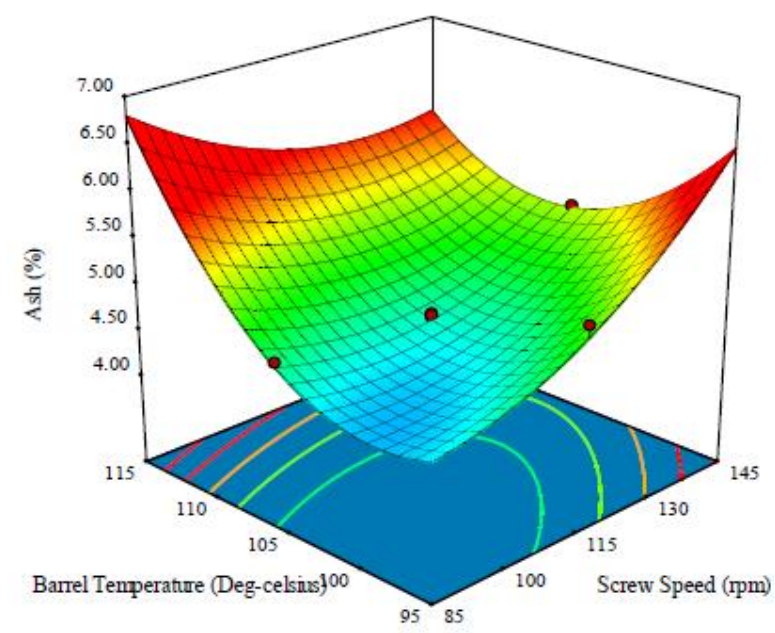

Figure 1. Impact of barrel temperature and screw speed on Ash 


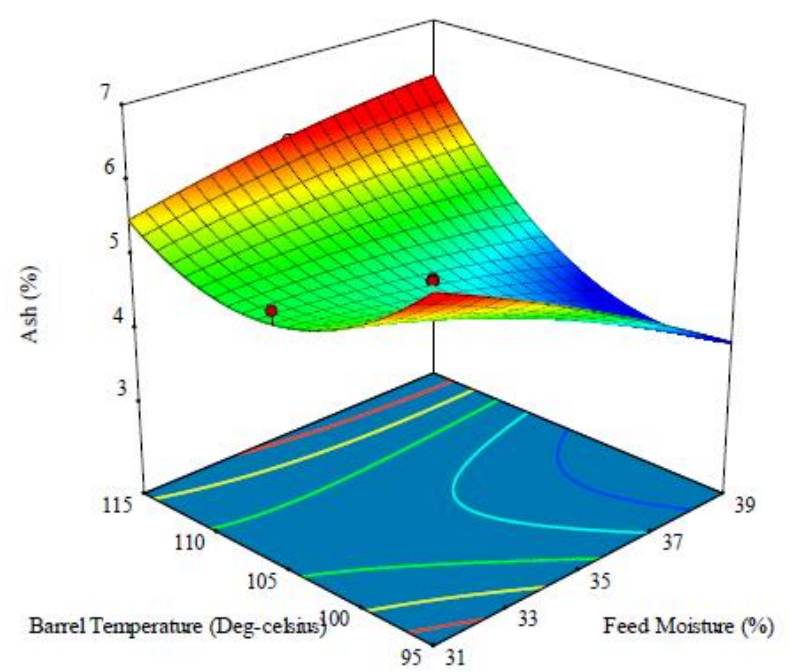

Figure 2. Impact of Barrel temperature and Feed moisture on Ash

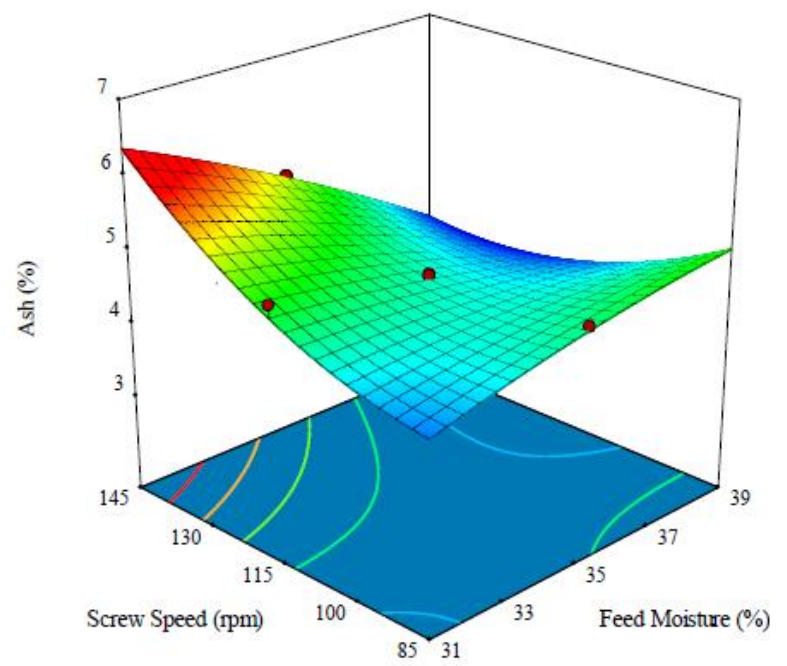

Figure 3. Impact of screw speed and feed moisture on Ash

Fig 1 to 3 show the impact of extrusion process parameters (barrel temperature, screw speed and feed moisture) on the ash contents of extruded aerial yam-soybean flour blends.

In Fig 1, which depicts the response surface plots for the impacts of barrel temperature and screw speed on ash, increase in barrel temperature and screw speed led to a corresponding increase in ash contents of the extrudates.

The effect of barrel temperature and feed moisture on the ash contents of the extrudates is presented in Figure 2. From the plot, it was observed that increase in barrel temperature tends to increase the ash contents, while increase in feed moisture decreased the ash contents of the extrudates.

Figure 3, which shows the effect of screw speed and feed moisture on the ash contents of the extrudates, indicated that increase in both the screw speed and feed moisture resulted in proportionate increase in the ash contents of the extrudates.

Analysis of variance (ANOVA) for the effects of barrel temperature, screw speed and feed moisture on ash contents showed that only the barrel temperature had statistical significant effect $(p<0.05)$ on ash, More so, screw speed and feed moisture had statistical insignificant effect on ash.

Test of between-subjects effects" of the extrusion process parameters on ash showed that the interactions of the extrusion process parameters significantly $(p<0.005)$ affected the ash contents of the extrudates. 


\subsection{Impact of Extrusion Process Parameters on Moisture Content}

Figure 4 to 6 below, present the response surface plots for the effect of barrel temperature, screw speed and feed moisture on moisture content of the extruded aerial yam-soybean flour blends.

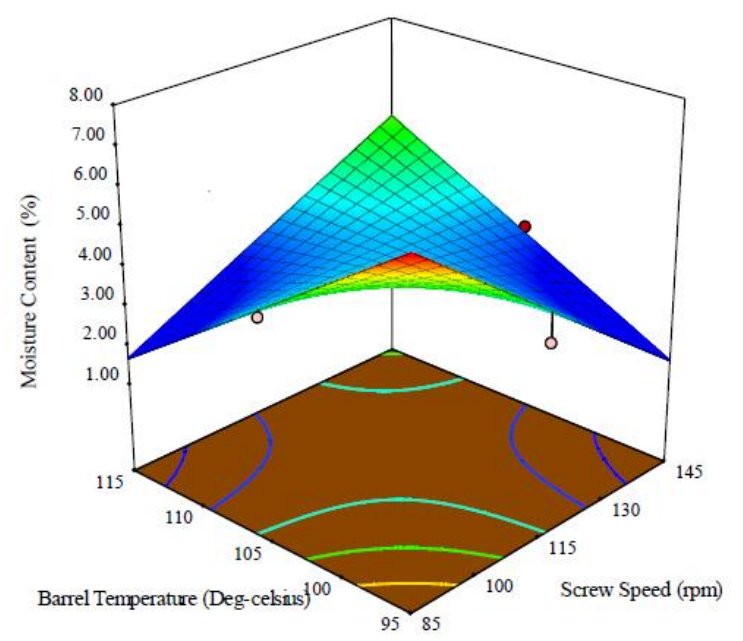

Figure 4. Impact of barrel temperature and screw speed on moisture content

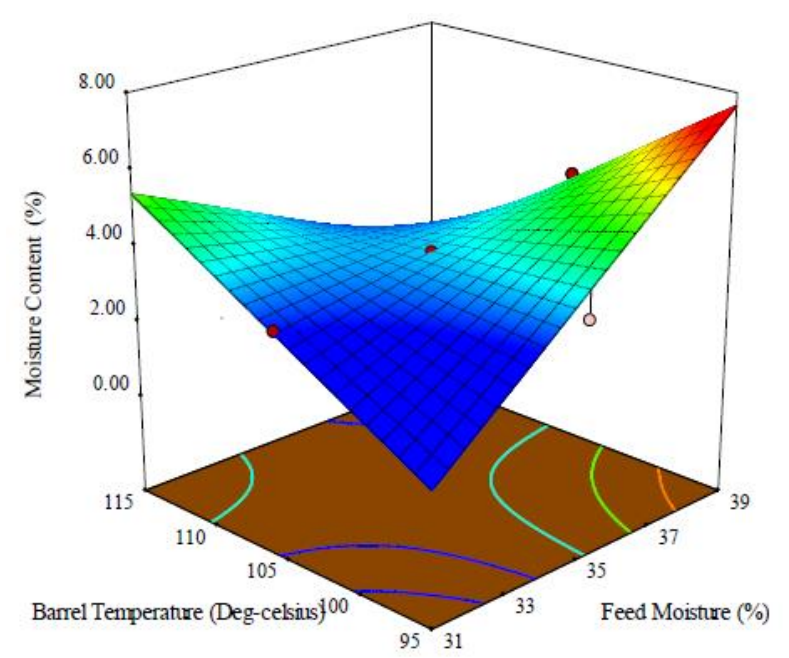

Figure 5. Impact of barrel temperature and feed moisture on Moisture Content

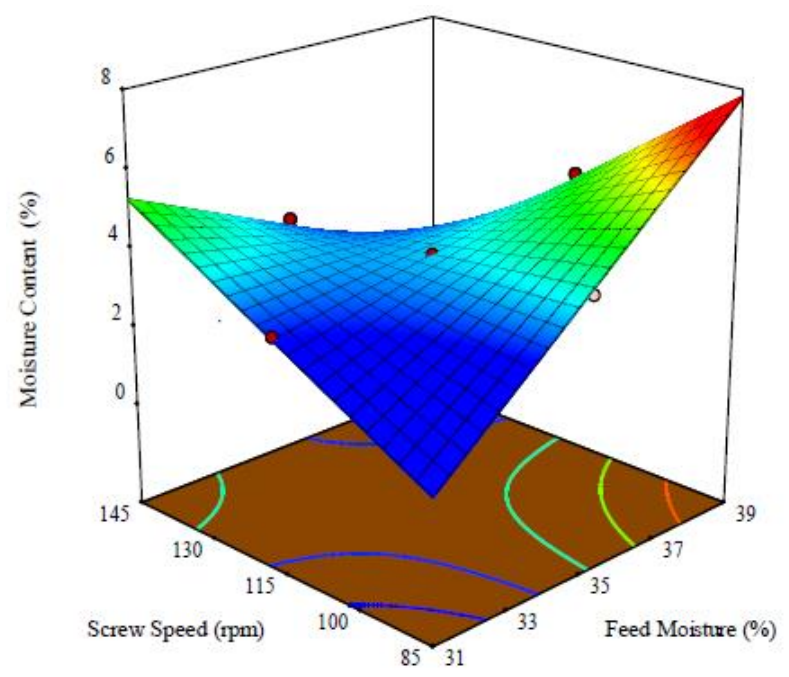

Figure 6. Impact of screw speed and Feed moisture on Moisture content 
In Figure 4, the Response surface plot for the impact of barrel temperature and screw speed on moisture content showed that expansion in barrel temperature and screw speed brought about relating decline in moisture content of the extrudates. This perception is in concurrence with that of Omohimi et al. (2014) and Ajita and Jha (2017).

The impact of barrel temperature and feed moisture on the moisture content of the extrudates is portrayed in Figure 5. It was seen from the plot that, expansion in barrel temperature prompted decline in moisture substance, while expansion in feed moisture prompted comparing expansion in moisture substance of the extrudates.

In Figure 6, the reaction surface plot for the impact of screw speed and feed moisture is like that of barrel temperature and feed moisture. Speed up prompted expansion in moisture substance, and expansion in feed moisture prompted a sharp expansion in moisture substance of the extudates. Extrusion cooking supported by high temperature and screw speed initiates underlying changes in food proteins as shrinkage that causes a tension driven progression of water out of the extrudates, which brought about decrease in water holding limit. This perception is in concurrence with that of Omohimi et al. (2014).

Examination of change (ANOVA) for the impact of barrel temperature, screw speed and feed moisture on moisture substance of the extrudates demonstrated that the three interaction boundaries (barrel temperature, screw speed and feed moisture) had no measurable critical impact ( $p>0.05)$ on moisture substance of the extrudates.

Trial of between-subjects impacts" of the extrusion cycle boundaries on moisture content demonstrated that the connections of the interaction boundaries fundamentally $(\mathrm{p}<0.05)$ impacted the moisture substance of the extrudates.

\subsection{Impact of Extrusion Process Parameters on Fibre}

In Figure 7, the response surface plot for the effect of barrel temperature and screw speed showed that increase in both the barrel temperature and screw speed resulted in increased fibre contents of the extrudates.

In Figure 8, increase in barrel temperature and feed moisture led to increase in fibre contents of the extrudates.

The same trend was observed in Fig 9 (Response surface plot for the impact of screw speed and feed moisture on fibre). Increase in screw speed led to increase in fibre contents, increase in feed moisture also resulted in increased level of fibre in the extrudates.

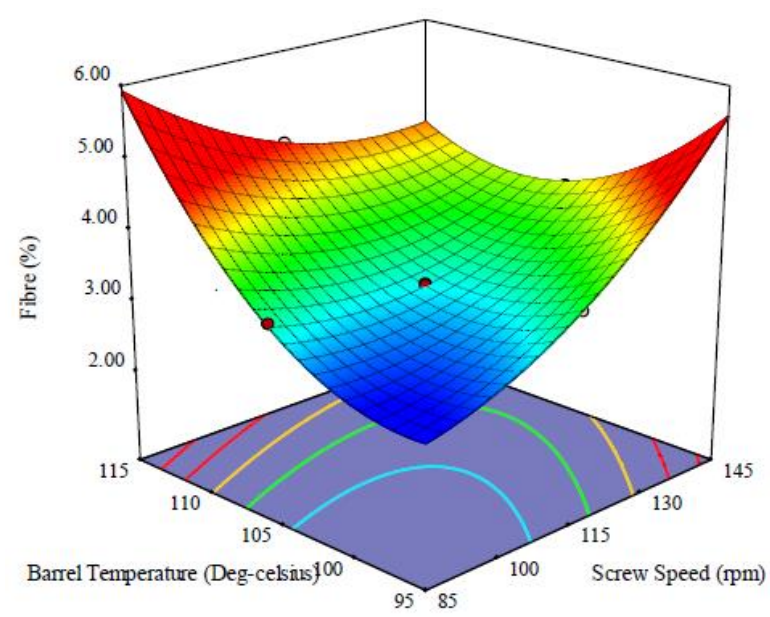

Figure 7. Impact of barrel temperature and screw speed on Fibre 


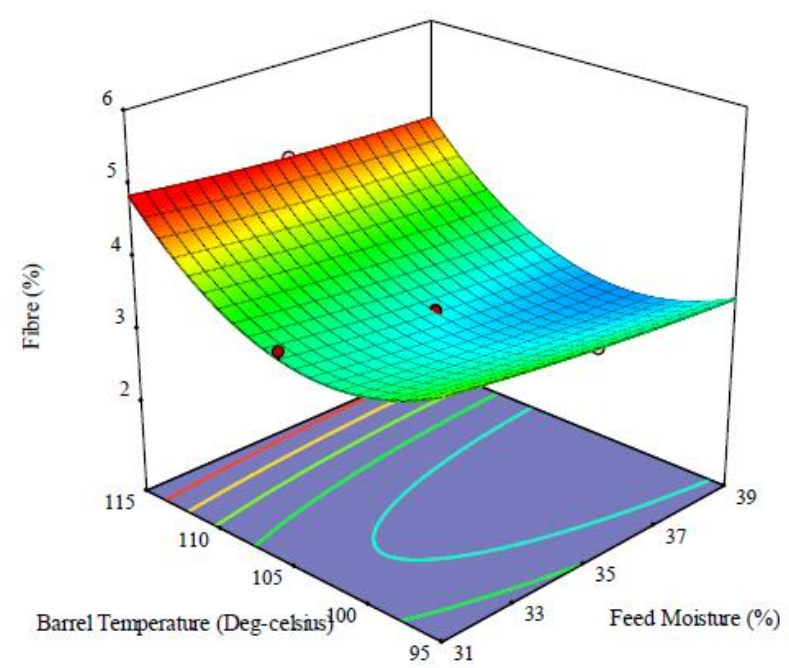

Figure 8. Impact of barrel temperature Feed moisture on Fibre

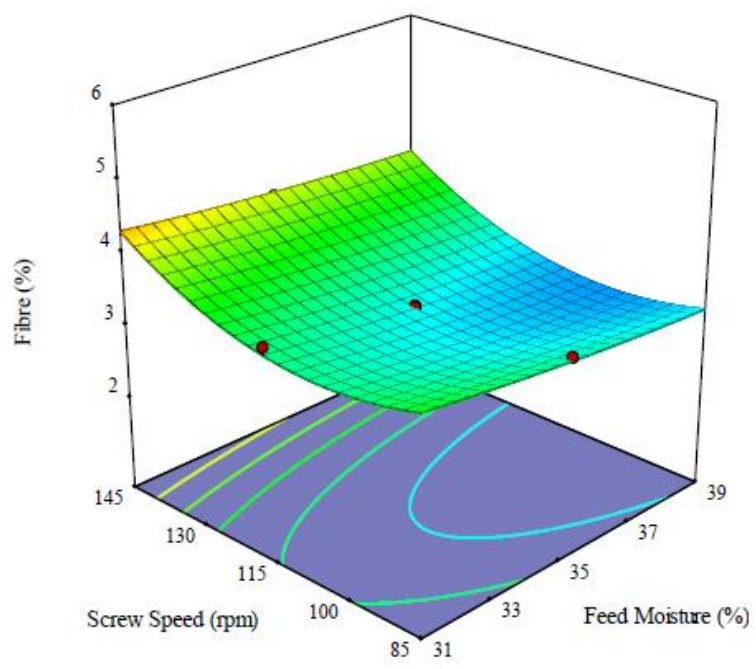

Figure 9. Impact of screw speed and feed moisture on Fibre

Analysis of variance (ANOVA) for the impact of barrel temperature, screw speed and feed moisture on fiber substance of the extudates showed that the barrel temperature and screw speed showed measurably huge impact $(p<0.05)$ on the fiber content of the extrudates, while the impact of feed moisture on fiber substance of the extrudates was genuinely immaterial $(\mathrm{p}>0.05)$. Trial of between-subjects impact of the expulsion cycle boundaries on fiber showed that the cooperations of barrel temperature and feed moisture; barrel temperature, screw speed and feed moisture fundamentally $(p<0.05)$ impacted fiber, while the associations of barrel temperature and screw speed; screw speed and feed moisture inconsequential $(\mathrm{p}>0.05)$ impacted the fiber substance of the extrudates.

\subsection{Impact of Extrusion Process Parameters on Protein}

The Response surface plots for the impact of extrusion process parameters (barrel temperature, screw speed and feed moisture) on the protein contents of the extruded aerial yam-soybean flour blends are presented in Figure 10 to 12 . 


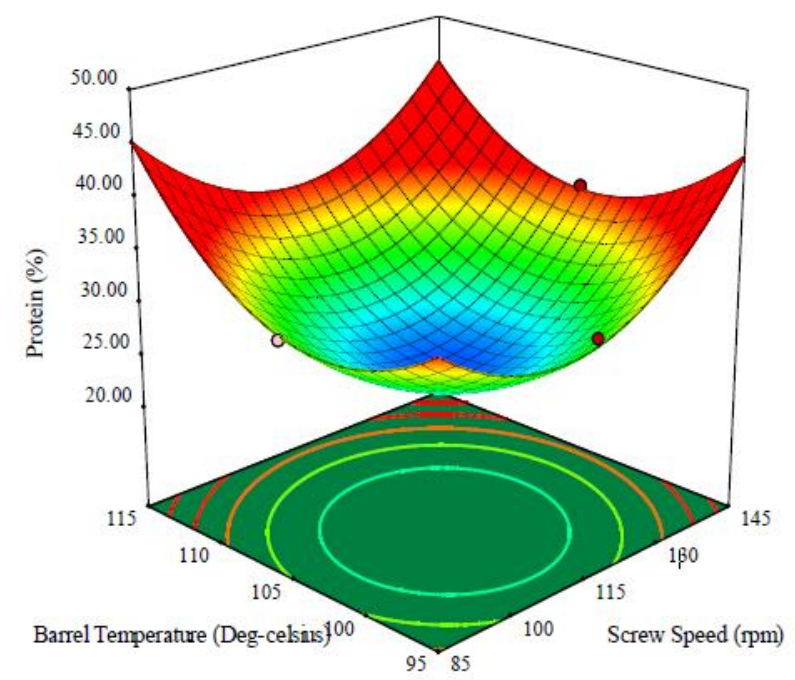

Figure 10. Impact of barrel temperature and screw speed on Protein

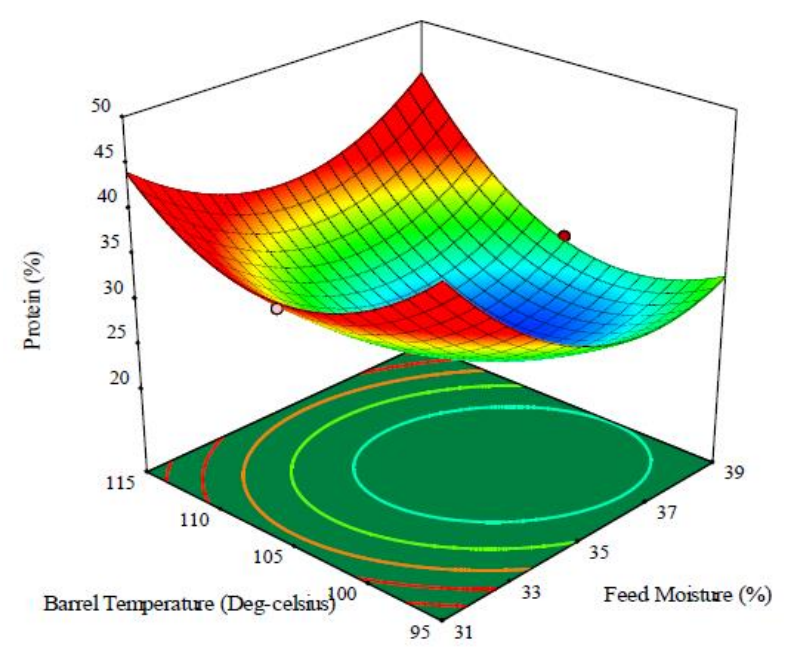

Figure 11. Impact of barrel temperature and feed moisture on Protein

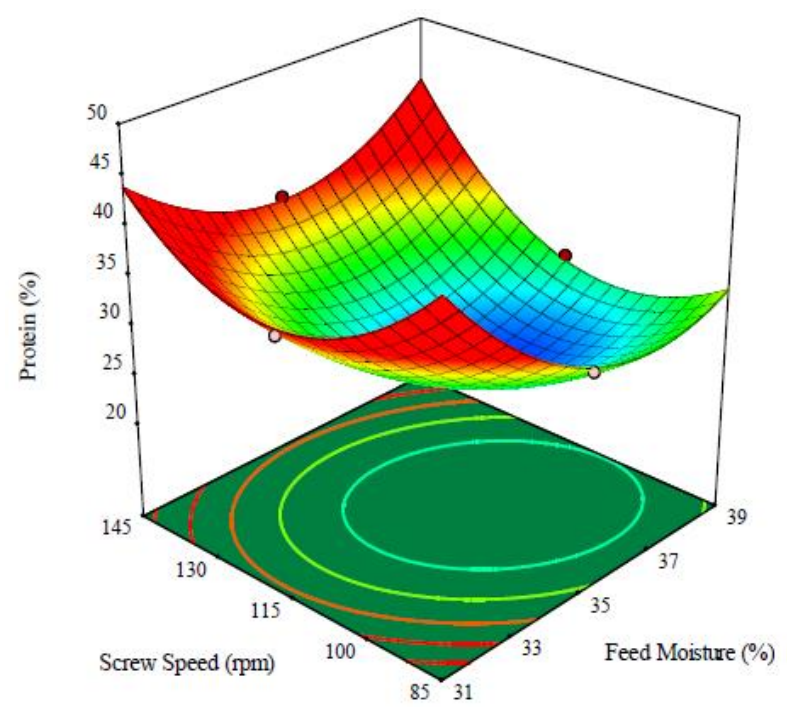

Figure 12. Impact of screw speed and feed moisture on Protein

In Fig 10, the Response surface plot for the impact of barrel temperature and screw speed on protein, showed 
that increase in both the barrel temperature and screw speed of the extruder led to quadratic increase in protein content of the extrudates.

In Fig 11, it is shown that increase in barrel temperature and feed moisture led to quadratic increase in protein, but the increase in protein with increase in barrel temperature is higher than that with increase in feed moisture.

The same trend was observed in the effect of screw speed and feed moisture on protein. Increase in the screw speed of the extruder and feed moisture led to quadratic increase in protein, but the increase is much higher with increasing screw speed than with increased feed moisture (Fig 12).

Analysis of variance (ANOVA) for the effect of barrel temperature, screw speed and feed moisture on the protein contents of the extrudates indicated that the three extrusion process parameters (barrel temperature, screw speed and feed moisture) were statistically significant $(p<0.05)$. Hence, they showed significant effect on the protein contents of the extrudates.

The result of the "Test of between-subjects effect" of the extrusion process parameters on protein indicated that the interactions of the process parameters showed significant $(p<0.05)$ effect on the protein content of the extrudates.

\subsection{Impact of Extrusion Process Parameters on Crude Fat (Lipid)}

The Response surface plot for the impact of extrusion process parameters (barrel temperature, screw speed and feed moisture) on the lipid contents of the extruded aerial yam-soybean flour blends are presented in Fig 13 to 15 .

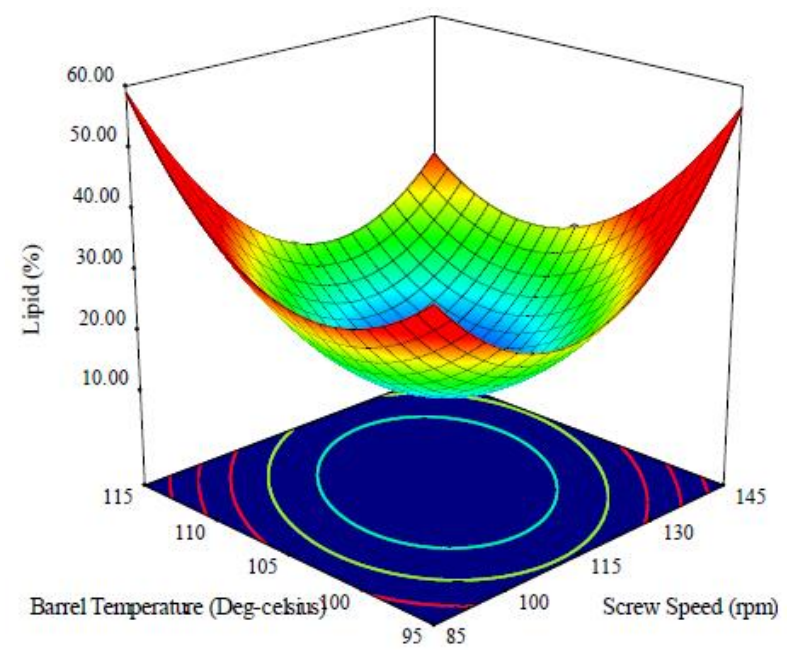

Figure 13. Impact of barrel temperature and screw speed on Crude fat (Lipid)

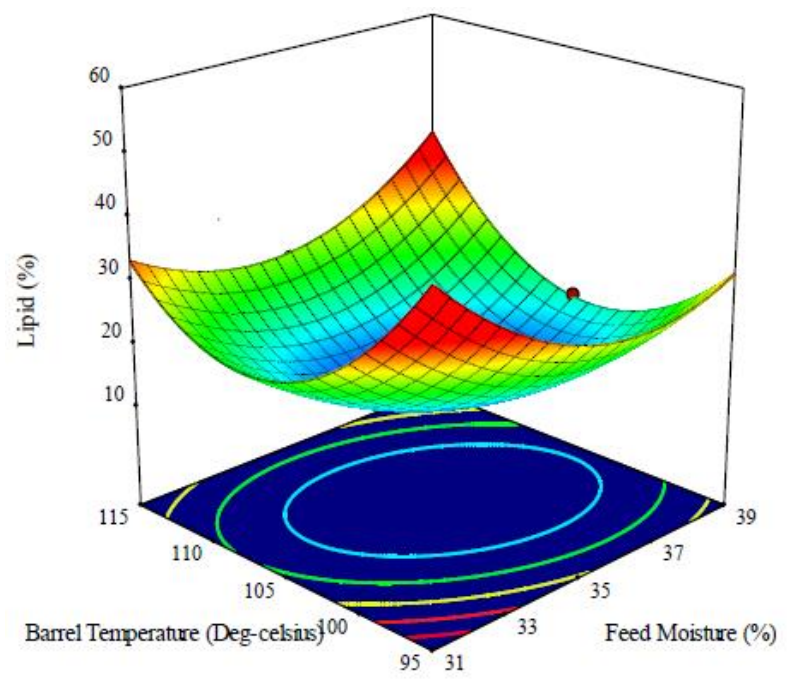

Figure14. Impact of barrel temperature and feed moisture on crude fat (Lipid) 


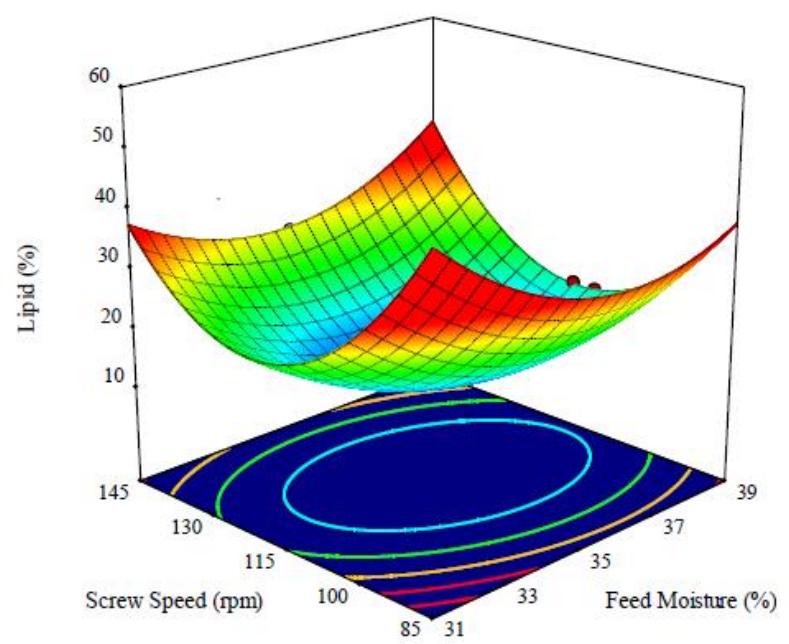

Figure 15. Impact of screw speed and feed moisture on crude fat (Lipid)

Increase in both barrel temperature and screw speed of the extruder led to a sharp quadratic increase in crude fat contents of the extrudates (Figure 13).

The impact of barrel temperature of the extruder and feed moisture on lipid is shown by the Response surface plot in Fig 14. It was observed that increase in both barrel temperature and feed moisture led to corresponding quadratic increase in the lipid contents of the extrudates.

Similarly, the Response surface plot for the impactt of screw speed and feed moisture on lipid showed that increase in both the screw speed of the extruder and feed moisture resulted in quadratic increase in the lipid contents of the extrudates (Fig 15).

Analysis of variance (ANOVA) for the effect of barrel temperature, screw speed and feed moisture on the crude fat contents of the extrudates showed that the three process parameters (barrel temperature, screw speed and feed moisture) had significant effect $(p<0.05)$ on the lipid contents of the extrudates.

The results of the "Tests of between-subjects effects" of the extrusion process parameters on crude fat showed that all the interactions of the extrusion parameters affected the fat contents of the extrudates significantly $(p<$ $0.05)$.

\section{Conclusion}

This study has shown that extrusion process conditions: barrel temperature; screw speed; feed moisture, and their collaborations have both positive and adverse impact on the extruded aerial yam-soybean flour blends.

Just barrel temperature has huge effect on the Ash content, while screw speed and feed moisture has non-critical impact on the Ash content of the extrudates.

All the extrusion variables (barrel temperature, screw speed and feed moisture) has non-huge impact on moisture content, while the association of the extrusion variables was shown to have critical impact on the moisture content of the extrudates.

The barrel temperature and the screw speed have critical impact on the fiber content, while feed moisture has measurably non-huge impact on the fiber content of the extrudates.

The extrusion process conditions, with their associations altogether influenced the protein and crude fat content of the extrudates.

This study has shown that the best extrusion condition blends are $115^{\circ} \mathrm{C}$ barrel temperature, $115 \mathrm{rpm}$ screw speed and $35 \%$ feed moisture for ash content; $100^{\circ} \mathrm{C}$ barrel temperature, 130rpm screw speed and $33 \%$ feed moisture for moisture content; $115^{\circ} \mathrm{C}$ barrel temperature, $115 \mathrm{rpm}$ screw speed and $35 \%$ feed moisture for fiber content; $105^{\circ} \mathrm{C}$ barrel temperature, $145 \mathrm{rpm}$ screw speed and $35 \%$ feed moisture for protein content; $105^{\circ} \mathrm{C}$ barrel temperature, $85 \mathrm{rpm}$ screw speed and $35 \%$ feed moisture for lipids.

The outcomes got for the general structures of the extrudates can authenticate the way that it is feasible to get extruded products, with dietary benefit, from aerial yam-soybean flour blends by extrusion handling innovation. 


\section{References}

Ahmed, Z., Chishti, M. Z., Johri, R. K., Bhagat, A., Gupta, K. K., \& Ram, G. (2009). Antihyperglycemic and antidyslipidemic activity of aqueous extract of Dioscoreabulbifera tubers. DioscoreaCroatica. pp. 38-39.

Ajita, T., \& Jha S. K. (2017). Extrusion Cooking Technology: Principal Mechanism and Effect on Direct Expanded Snacks - An Overview. International Journal of Food Studies, 6(1), 113-128. https://doi.org/10.7455/ijfs/6.1.2017.a10

Akonor, P. T., Tortoe, C., Buckman, E. S., \& Hagan, L. (2017). Proximate Composition and Sensory evaluation of root and tuber composite flour noodles. Cogent Food and Agriculture, 3(1), 1292586. https://doi.org/10.1080/23311932.2017.1292586

AOAC. (1990). Official Methods of Analysis of the Association of Official Analytical Chemists. Washington D. C.

Brand-Miller, J., Burani, J., \& Foster-Powell, K. (2003). The new glucose revolution pocket guide to the top 100 low GI foods (2nd ed.). Marlowe \& Company.

Brncic, M., Tripalo, B., Jezek, D., Semenski, D., Drvar, N., \& Ukrainczyk, M. (2006). Effect of twin-screw extrusion parameters on mechanical hardness of direct-expanded extrudates. Sadhana, 31(5), 527-536. https://doi.org/10.1007/BF02715911

Castells, M., Martin, S., Sanches, V., \& Ramos, A. J. (2005). Fates of mycotoxins in cereals during extrusion cooking: a review. Food Additives and Contaminants, 22, 150-157. https://doi.org/10.1080/02652030500037969

Coursey, D. G. (1967). Yams. An account of the nature, cultivation and utilization of major root crops with special emphasis on human, Animal, Industrial uses. Tropical Root Crops. IDRC 22. Ottawa. pp. 25-35.

Gaossong, J., \& Vasanthan, T. (2000). The effect of extrusion cooking on the primary structure and water solubility of b-glucans from regular and waxy barley. Cereal Chemistry, 77, 396-400. https://doi.org/10.1094/CCHEM.2000.77.3.396

Igyor, M. A., Ikjo, S. M., \& Germah, D. I. (2004). The food potential of potato yam (Discoreabulbifera). Nigerian Food Journal, 29. https://doi.org/10.4314/nifoj.v22i1.33590

Iwe, M. O. (2003). The Science and Technology of Soybean: Chemistry, Nutrition, Processing, Utilization. Rojoint Communication Services Ltd, Enugu, Nigeria. pp. 1-6.

Iwe, M. O. (1997). Optimization of Engineering, Functional and Nutritional properties of Single-screw Extruded Soy-sweet Potato Blends for Food use by Response Surface Methodology. University of Nigeria Research Publications.

Kareem, S. T., Adebowale, A. A., Sobukola, O. P., Adebisi, M. A., Obadina, O. A., Kajihausa, O. E., Adegunwa, M. O., Sanni, L. O., \& Keith, T. (2015). Some quality attributes of high quality cassava-tigernut composite flour and its extruded snacks. Journal of Culinary Science and Technology, 13, 242-262. https://doi.org/10.1080/15428052.2015.1015667

Nwosu, J. N. (2013). Evaluation of the functional and sensory properties of biscuits produced from aerial yam (Discoreabulbifera). International Science and Investigation Journal, 2(5), 1-17.

Ojinnaka, M. C., Okudu, H., \& Uzosike, F. (2017). Nutrient Composition and Functional Properties of Major Cultivars of Aerial Yam (Dioscoreabulbifera) in Nigeria. Food Science and Quality Management, 62. Retrieved from www.iiste.org

Olurin, T. O., Arisa, N. U., \& Aworh, O. C. (2006). Influence of pre-treatments of drying characteristics of pre-treated yam slices. International Conference on Engineering Research and Development (ICER\&D 2006) Proceedings held at Benin City, Nigeria. pp. 389-392.

Omohimi, C. I., Sobokola, O. P., Sarafaden, K. O., \& Sanni, L. O. (2014). Effect of Thermo-extrusion Process Parameters on Selected Quality Attributes of Meat Analogue from Mucuna Bean Seed Flour. Nigerian Food Journal, 32(1), 21-30. https://doi.org/10.1016/S0189-7241(15)30092-8

Orkwor, G. C., Asiedu, R. S., \& Ekanayak, I. J. (1998). Food yams. Advances in Research: International Institute Tropical Agriculture (IITA) Ibadan and National Root Crops Research Institute, (NRCRI) Umudike. pp. $187-215$.

Princewill-Ogbonna, I. L., \& Ezembaukwu, N. C. (2015). Effect of Various Processing Methods on the Pasting 
and Functional Properties of Aerial Yam (Dioscoreabulbifera) Flour. British Journal of Applied Science \& Technology, 9(5), 517-526. https://doi.org/10.9734/BJAST/2015/17915

Sanful, R. E., \& Engmann, F. N. (2016). Physico-Chemical and Pasting Characteristics of Flour and Starch from Aerial Yam. American Journal of Food Science and Nutrition, 3(1), 1-7.

Strahm, B. S. (2000). Preconditioning. In M. N. Riaz, (Ed). Extruders in food applications (pp. 115-126). Boca Raton: CRC Press.

Tadesse, S. A., Bultosa, G., \& Abera, S. (2019). Chemical and Sensory quality of sorghum-based extruded product supplemented with defatted soy meal flour. Cogent Food and Agriculture, 5(1), 1-19.

https://doi.org/10.1080/23311932.2019.1653617

\section{Copyrights}

Copyright for this article is retained by the author(s), with first publication rights granted to the journal.

This is an open-access article distributed under the terms and conditions of the Creative Commons Attribution license (http://creativecommons.org/licenses/by/4.0/). 